\title{
The Effect of Economic Growth on Carbon Dioxide Emissions in Sub-Saharan Africa: Decomposition into Scale, Composition and Technique Effects
}

\author{
Hilaire Nkengfack*, Hervé Kaffo Fotio, Serge Temkeng Djoudji \\ LAREFA, Faculty of Economics and Management, University of Dschang, Dschang, Cameroon \\ Email: ^h.nkengfack@gmail.com, *hilaire.nkengfack@univ-dschang.org,kaffofotioherve@yahoo.fr, \\ rvkfo19@gmail.com,tdserge@yahoo.fr
}

How to cite this paper: Nkengfack, $\mathrm{H}$., Kaffo Fotio, H. and Temkeng Djoudji, S. (2019) The Effect of Economic Growth on Carbon Dioxide Emissions in Sub-Saharan Africa: Decomposition into Scale, Composition and Technique Effects. Modern Economy, 10, 1398-1418.

https://doi.org/10.4236/me.2019.105094

Received: February 1, 2019

Accepted: May 21, 2019

Published: May 24, 2019

Copyright $\odot 2019$ by author(s) and Scientific Research Publishing Inc. This work is licensed under the Creative Commons Attribution International License (CC BY 4.0).

http://creativecommons.org/licenses/by/4.0/

\begin{abstract}
The objective of this paper is to decompose the effects of economic growth on carbon emissions into scale, composition and technique effects in a panel of 23 Sub-Saharan African countries between 1996 and 2014. We combine static and dynamic panel estimation technique to quantile regression technique in order to bring out a detailed description of the relationship between carbon emissions and its determinants at different levels of carbon dioxide emissions. The results from static and dynamic estimations reveal that the expansion in the scale and the composition of the economy increase carbon emissions, while improvements in the technology are sufficient to reduce carbon emissions. However, quantile regressions indicate that these three effects are heterogeneously distributed across the dioxide carbon emission levels, and the scale effect holds only at the lower quantiles. The results also indicate that financial development, the size of population and the exports (as a percentage of GDP) have a positive effect on carbon emission, while imports (as a percentage of Gross Domestic Product) reduce it.
\end{abstract}

\section{Keywords}

Carbon Emissions, Economic Growth, Scale Effect, Composition Effect, Technique Effect

\section{Introduction}

Since independence, Sub-Saharan African (SSA) countries have introduced several reforms aimed at achieving high rates of economic growth or supporting 
economic growth during economic slack. Looking at recent data, the gross domestic product (GDP) in SSA countries increased remarkably from 634,279 G \$ (constant 2010) in 1990 to 1749 T \$ (constant 2010) in 2017, with an average growth rate of $3.73 \%$. In spite of this positive economic growth, the region is still facing increasing challenges in terms of development outcomes. For instance, the region is mainly made up of least developed countries, with low human Development Indicators (HDI). ${ }^{1}$ Also, $20 \%$ of people in this region were undernourished in 2015 and this was expected to rise to $22 \%$ in 2016 [1].

The quest for economic growth has been associated with an increase in the emissions of greenhouse gases, particularly carbon dioxide emissions. In fact, SSA countries faced a rapid increase in carbon emissions during the past two decades. According to the World Bank [2], the annual volume of carbon emissions increased in SSA by $87.5 \%$ between 1990 and 2017. SSA recorded the third lager increase in carbon emissions behind the Middle East and North Africa and Asia, with an average increase of 225\% and 196\%, respectively between 1990 and 2015 [3].

Although this region is responsible for less than 3\% of world's energy-related carbon emissions in 2015 [3], it is widely recognized that the region is less resilient to the adverse effects of global warming than other developing regions. In fact, global warming has emerged as one of the critical challenges facing the human society. Greenhouse gas emissions (GHGs), especially carbon dioxide emissions, are considered as a dominant contributor to global warming [4]. Among its consequences is the growing risk of catastrophic global climate change which threatens to weaken food production systems; increase the intensity and frequency of droughts, floods, and fires; and undermine gains in development and poverty reduction [5]. Understanding the drivers of carbon emissions will help to implement effective policies to combat it.

The impact of economic growth on environmental quality has been extensively discussed in the economic literature during the past two decades. Grossman and Krueger [6] and the World Bank [7] hold that the relationship between economic growth and environmental degradation is described by an inverted U-shaped curve, known as the environmental Kuznets curve (EKC). According to the EKC, at low incomes, economic development is associated with environmental degradation, while an inverse relationship is observed at high income levels. A voluminous literature has tested the validity of the EKC in Sub-Saharan Africa. However, empirical results are mixed and inconclusive. A possible explanation of the contradictions is that authors assess the EKC ignoring the importance of structural effects that drive economic growth.

In fact, the effect of economic growth on the environment is determined by the relative importance of the scale, composition and technique effects. ${ }^{2}$ To the

${ }^{1}$ Only Gabon, Mozambique and South Africa are listed as high HD countries. Other are listed in the category of lower HD countries and most important, seventeen countries from SSA were listed in the top twenty of countries with lower HDI.

${ }^{2} \mathrm{~A}$ detailed description of these effects is presented in the literature review. 
best of our knowledge, this is the first study to decompose the effect of economic growth on carbon emissions into the scale, composition and technique effects in Sub-Saharan Africa context. Previous studies were carried out on a large sample of countries [8], a single country out of Africa [9] or on deforestation in the Congo Basin [10]. Complement to the three structural effects, we use additional variables in our models to account for omission variable bias as suggested by Ang [11]. Furthermore, we combine several estimation techniques to handle some econometric issues such as the endogeneity of our variables, the omitted variables bias and the non-normal distribution of the variables. To account for the first two issues, we use the Generalized Moments Method (GMM), while the quantile regression technique helps us to address the problem of the conditional distribution of $\mathrm{CO}_{2}$ emissions. Lastly, this is probably the first study that employs the quantile approach to decompose the environmental effect of economic growth into scale, composition and technique effects.

The rest of the paper is organized in four main sections. Section 2 connects the study with previous literature on the subject, Section 3 discusses the data and the empirical approach, Section 4 presents the results and discussions and the last section, Section 5, presents the concluding remarks and the policy implications of the study.

\section{Literature Review}

The environmental effect of economic growth has attracted a special attention in the literature since the seminal works of Grossman and Krueger [6]. These authors use three measures of air pollution to study the relationship between air quality and economic growth. The results show for two pollutants (sulfur dioxide and smoke) that concentrations increase with per capita GDP at lower level of the national income but decrease with GDP growth at higher levels of income. Based on this result, they conclude that the relationship between economic growth and environmental degradation is described by an inverted-U shaped curve or an Environmental Kuznets Curve (EKC). ${ }^{3}$ The EKC is similar to the original curve proposed by Simon Kuznets [12] concerning the relationship between income inequality and economic growth.

Among the determinants of the EKC, Grossman and Krueger [6], Panayotou [13] and Copeland and Taylor [14] indicate that the rise and fall of the curve are explained by the combination of the three structural effects associated to economic development: scale, composition and technique effects. From the studies by Brock and Taylor [15], Jobert and Karanfil [16] and Bakehe [10], these effects are summarized in the following equation:

$$
\hat{E}=\hat{Y}+\sum_{i}^{n} \pi_{i} \hat{s}_{i}+\sum_{i}^{n} \omega_{i} \hat{a}_{i}
$$

\footnotetext{
${ }^{3}$ This appellation is attributed to Panayotou [13].
} 
where: $\hat{E}$ is the amount of pollution, $\pi_{i}$ and $\omega_{i}$ are the shares of the composition and technique effects in total pollutant emissions.

$\hat{Y}$ represents the scale effect and captures the effect of a unit change in the volume of production on pollution. Assuming that the composition of output and the state of technology remain unchanged (that is $\hat{s}_{i}=\hat{a}_{i}=0$ ), a unit increase in the scale of the production will generate more and more pollution.

$\sum_{i}^{n} \pi_{i} \hat{s}_{i}$ is the composition effect or the structure of output. It captures the effect of a unit change in the output structure on the level pollutant emissions. In fact, the composition effect has damaging impacts on the environment when economies move from agricultural to industrial-based goods, while the impact on the environment is positive when the economies move from industry to service-based goods and services.

$\sum_{i}^{n} \omega_{i} \hat{a}_{i}$ is the technique effect and captures the effect of technological progress on the environment. In fact, any improvement of the technical coefficients will result in a deceleration of the rate of increase of environmental degradation. Moreover, the putting in place of rigorous environmental regulations due to the awareness of the public to environmental problems will also lead to a reduction in environmental degradation.

Figure 1 presents the dynamic relationship between structural change and the environmental quality. It is observed that at lower income levels (left-side of Figure 1), the technique effect is dominated by the scale and composition effects. In this stage, economic growth is conducted by pollution-intensive activities such as agriculture and the industrial sectors. However, the reverse effect is observed at higher income levels (right-side of Figure 1) where the scale effect is dominated by the combination of the composition and technique effects. This results from the improvement in technique of production and the shift from the industrial sector to the tertiary sector, which is less pollution-intensive than the industrial sector.

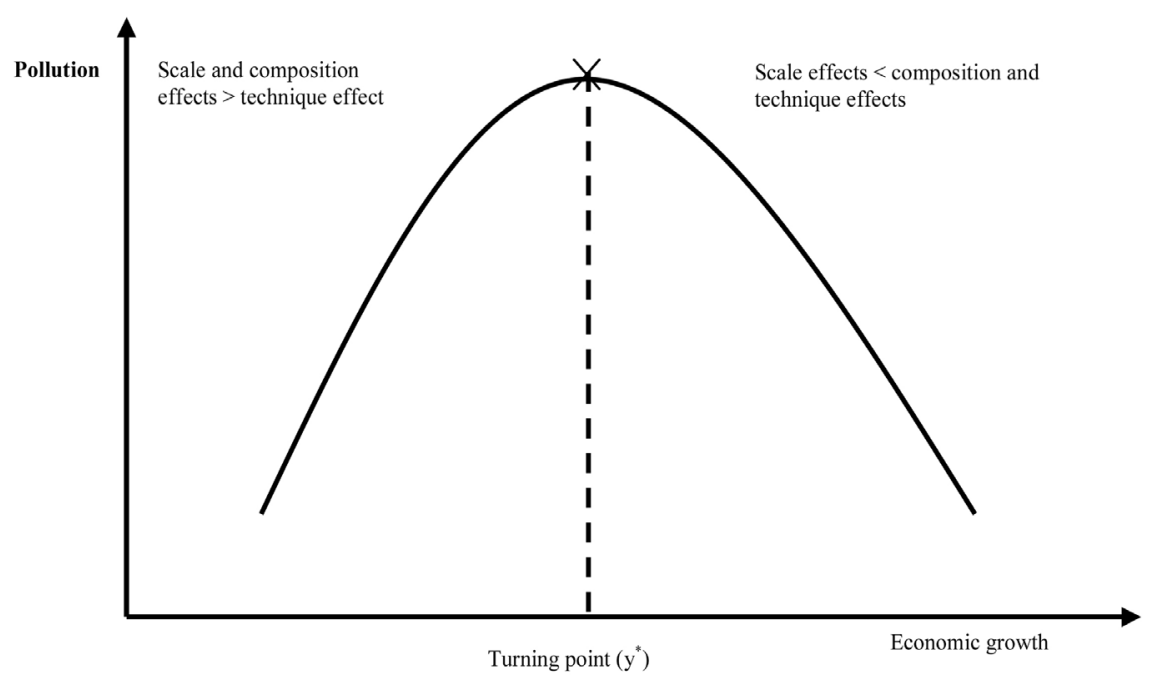

Figure 1. Structural change and the EKC. Source: Adapted from Stern [17]. 
Figure 2 summarizes the expected signs associated to overall effects economic growth on the environmental quality. It should be noted that the scale effect is always associated to an increase in the pollution level (positive sign), while the composition effect has mixed effects depending on the capital intensity of economic growth. In fact, if higher capital intensity is associated with more pollution-oriented industries, then any increase in the composition will generate more pollution. Otherwise, the resulting effect will be negative. The technique effect reflects the changes in production methods that usually reduce emissions per unit of output, and therefore we expect a negative slope over all income levels. The net effect of economic growth will therefore be determined by the respective weights of the scale, composition and technique effects and could be either positive or negative.

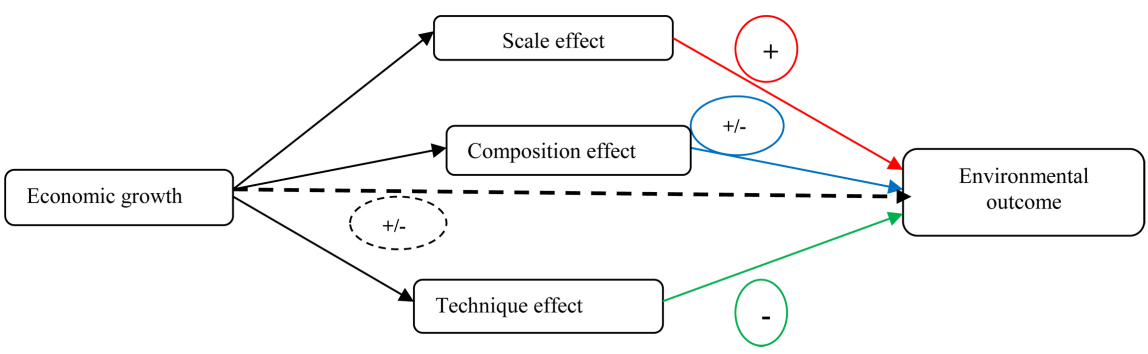

Figure 2. Decomposition of environmental impacts into scale, composition and technique effects. Source: Constructed by authors.

At the empirical level, a large number of studies have investigated whether the theoretical predictions on the structural effects hold. The literature on the topic is segmented into two strands. The first strand is made up of studies aimed at exploring the EKC hypothesis. Authors use different functional specifications, time periods, countries or regions and econometric techniques to investigate the EKC. Different results are found: a monotonic increasing relationship, a monotonic decreasing relationship, an inverted U-shaped relationship, a U-shaped relationship, an $\mathrm{N}$-shaped relationship and an inverted $\mathrm{N}$-shaped relationship. ${ }^{4}$ Table 1 summarizes some recent studies on the relationship between economic growth and environmental degradation.

Contrary to previous literature in which authors used quadratic or cubic models to assess the dynamic effect of economic growth on the environment, authors of the second strand of the literature used to decompose the environmental effect of economic growth into scale, technique and composition effects. The main advantage of this decomposition is that it helps to better understand the specific effects of economic growth on the environment. For instance, $\mathrm{Pa}$ nayotou [13] examines the decomposed effect of economic growth on $\mathrm{SO}_{2}$ concentrations in a reduced-form of EKC model. He uses GDP per square kilometer, GDP per capita, and the share of industry in GDP as proxies of scale, technique,

${ }^{4}$ For a more detailed literature review of the empirical assessment of the EKC hypothesis, see Mardani et al. [27], Sarkodie and Strezov [28], Kaika and Zervas [29], Dinda [30]. 
Table 1. Recent literature on the ECK hypothesis.

\begin{tabular}{|c|c|c|c|c|c|}
\hline $\begin{array}{l}\text { Authors } \\
\text { (year) }\end{array}$ & $\begin{array}{l}\text { Sample } \\
\text { (Period) }\end{array}$ & $\begin{array}{c}\text { Environmental } \\
\text { variables }\end{array}$ & $\begin{array}{l}\text { Econometric } \\
\text { specification }\end{array}$ & $\begin{array}{l}\text { Estimation } \\
\text { technique (s) }\end{array}$ & Results \\
\hline \multicolumn{6}{|c|}{ Selected studies that confirm the EKC } \\
\hline Pata [18] & $\begin{array}{c}\text { Turkey } \\
(1974-2014)\end{array}$ & $\mathrm{CO}_{2}$ emissions & Quadratic & $\begin{array}{l}\text { ARDL, FMOLS } \\
\text { and CCR }\end{array}$ & $\begin{array}{c}\text { ECK is valid with turning } \\
\text { points between } 13,523 \text { and } \\
14,077 \text { USD }\end{array}$ \\
\hline Hanif [19] & $\begin{array}{l}34 \text { SSA countries } \\
(1995-2015)\end{array}$ & $\mathrm{CO}_{2}$ emissions & Quadratic & System GMM & EKC is confirmed \\
\hline $\begin{array}{l}\text { Ahmad et } \\
\text { al. [20] }\end{array}$ & $\begin{array}{c}\text { India } \\
(1971-2014)\end{array}$ & $\begin{array}{c}\text { Aggregated and } \\
\text { disaggregated } \mathrm{CO}_{2}\end{array}$ & Quadratic & $\begin{array}{l}\text { ARDL bounds } \\
\text { testing and } \\
\text { causality test }\end{array}$ & $\begin{array}{l}\text { Confirmed for aggregated and } \\
\text { disaggregate } \mathrm{CO}_{2} \text { indicators }\end{array}$ \\
\hline $\begin{array}{l}\text { Heidari et } \\
\text { al. }[21]\end{array}$ & $\begin{array}{l}\text { Five ASEAN countries: } \\
\text { Indonesia, Malaysia, } \\
\text { Philippines, Singapore } \\
\text { and Thailand }\end{array}$ & Carbon dioxide & & PSTR & $\begin{array}{l}\text { EKC is supported for the } \\
\text { panel. }\end{array}$ \\
\hline \multicolumn{6}{|c|}{ Selected studies that reject the EKC } \\
\hline $\begin{array}{c}\text { Zoundi } \\
{[22]}\end{array}$ & $\begin{array}{l}25 \text { SSA countries } \\
\quad(1980-2012)\end{array}$ & $\mathrm{CO}_{2}$ emissions & Quadratic & $\begin{array}{l}\text { Dynamic OLS, Syst } \\
\text { GMM, DFE, MG, } \\
\text { PMG }\end{array}$ & $\begin{array}{l}\text { Monotonic increasing } \\
\text { relationship. }\end{array}$ \\
\hline Abid [23] & $\begin{array}{l}23 \text { SSA African countries } \\
\qquad(199-2010)\end{array}$ & $\mathrm{CO}_{2}$ emissions & Quadratic & $\begin{array}{l}\text { Static (Pooled OLS, } \\
\text { RE, FE) and } \\
\text { dynamic (diff } \\
\text { GMM, syst GMM } \\
\text { and LSDVC) panel } \\
\text { techniques }\end{array}$ & $\begin{array}{l}\text { Monotonic increasing } \\
\text { relationship. }\end{array}$ \\
\hline $\begin{array}{l}\text { Allard et } \\
\text { al. [24] }\end{array}$ & $\begin{array}{l}74 \text { countries } \\
(1994-2012)\end{array}$ & $\mathrm{CO}_{2}$ emission $_{\mathrm{s}}$ & Cubic & Quantile regression & $\mathrm{N}$-shaped relationship. \\
\hline \multicolumn{6}{|c|}{ Selected studies that provided mixed results } \\
\hline Keho [25] & $\begin{array}{l}59 \text { countries from different } \\
\text { regions and periods: } \\
\text { SSA and MENA } \\
(1976-2011) \\
\text { America, Asia and Europe } \\
\quad(1971-2011)\end{array}$ & $\mathrm{CO}_{2}$ emissions & Quadratic & Quantile regression & $\begin{array}{l}\text { EKC is confirmed for SSA, } \\
\text { American and European } \\
\text { countries at all quantiles. } \\
\text { EKC is valid for Asian and } \\
\text { MENA countries only at } \\
\text { lower levels of } \mathrm{CO}_{2} \text { emissions. }\end{array}$ \\
\hline $\begin{array}{l}\text { Alam et al. } \\
\quad[26]\end{array}$ & $\begin{array}{l}\text { Brazil, China, India and } \\
\text { Indonesia }(1970-2012)\end{array}$ & $\mathrm{CO}_{2}$ emissions & $\begin{array}{l}\text { Linear and } \\
\text { quadratic }\end{array}$ & $\begin{array}{l}\text { ARDL bounds } \\
\text { testing }\end{array}$ & $\begin{array}{l}\text { EKC is confirmed only in } \\
\text { Brazil, China and Indonesia } \\
\text { and rejected for India. }\end{array}$ \\
\hline
\end{tabular}

Notes: ARDL stands for Autoregressive Distributed Lag, FMOLS for Fully Modified Least Squares, CCR for canonical cointegrating regression, Diff and syst GMM for difference and system Generalized Method Moments, OLS for Ordinary Least Squares, LSDVC for Least Squares Dummy variables, RE is random effects model, FE is fixed effects model, PSTR is panel Smooth Transition Regression, MENA is Middle East and North Africa, SSA is Sub-Saharan Africa. Source: Authors' construction from the literature.

and composition effects respectively. The results reveal that sulfur dioxide $\left(\mathrm{SO}_{2}\right)$ concentrations decrease with the technique effect, while the scale and composition effects increase $\mathrm{SO}_{2}$ concentrations.

Tsurumi and Managi [8] use a semi parametric method of generalized additive models to decompose the determinants of environmental quality into scale, 
technique and composition effects. They use three proxies of environmental degradation to conduct their study, namely $\mathrm{SO}_{2}$ emissions, $\mathrm{CO}_{2}$ emissions and energy use. Three main results are obtained: 1) economic expansion, through the scale effect has a negative impact on the environment; 2) the composition effect (measured by the capital-labor ratio) has a nonlinear impact on the environment; and 3) the impact of technique effect is heterogeneous, depending on the proxy of environment. In fact, they conclude that the technique effect is sufficient to reduce $\mathrm{SO}_{2}$ emissions, while its effect is not enough to reduce $\mathrm{CO}_{2}$ emissions and energy use, except for the case of $\mathrm{CO}_{2}$ emissions in high-income countries.

Ling et al. [9] investigate the trade-environment relationship in Malaysia using time series data from 1970 to 2011. They decompose the effects of trade into scale, technique, composition and comparative advantage effects. Their results indicate that expansion in the scale of the economy increases $\mathrm{CO}_{2}$ emissions while the composition and technique effects moderate $\mathrm{CO}_{2}$ emissions. Also, they find that the comparative advantage effect increases carbon emissions.

Bakehe [10] decomposes the effects of the EKC for deforestation in the Congo Basin using a Kernel Non parametric regression approach. The results show that the scale and composition effects tend to increase deforestation rates in the selected countries. However, the technique effect does not hold, implying that improvements in technology lead to additional deforestation. The author attributes such a result to the fact that improvements in technical efficiency also improve the capacities of transformation of wood in the Congo Basin and the extension of arable land. This in turn, counterbalances the expected positive effect of technological progress in the sector.

To contribute to the literature on the effect of economic growth on carbon emissions in SSA, we decompose the economic growth into the scale, composition and technique effects. Also, in order to avoid omitted variable bias as suggested by Ang [11], we introduce size of the population, financial development, exports and imports as additional determinants of carbon emissions in this region. Unlike previous studies, we use several economic techniques to check the robustness of our results.

\section{Empirical Framework}

\subsection{Data and Definition of Variables}

This study aims at decomposing the effects of economic growth on carbon emissions in the following Sub-Saharan African countries: Angola, Benin, Botswana, Cameroon, Democratic Republic of Congo (DRC), Congo, Eritrea, Eswantini, Gabon, Kenya, Madagascar, Mali, Mauritius, Mozambique, Namibia, Nigeria, Rwanda, Senegal, South Africa, Sudan, Tanzania, Togo and Uganda. Due to data constraints, we use annual observations on each country over the 1996-2014 period. The said data is retrieved from the World Development Indicators [2].

The dependent variable is the level of carbon emissions in each country in kt. According to the World Bank's official definitions, $\mathrm{CO}_{2}$ emissions are "those 
stemming from the burning of fossil fuels and the manufacture of cement. They include carbon dioxide produced during consumption of solid, liquid, gas fuels and gas flaring".

Several variables have been used in the literature as proxy for the scale, composition and technique effects. Table 2 provides a description of variables generally used as such in the literature.

In this study, GDP per kilometer square is used as indicator of the scale effects. Given that the areas (in $\mathrm{km}^{2}$ ) of countries are fixed, increases in the value of GDP per kilometer square are automatically associated to expansion of economic activity. Based on theoretical predictions, the scale effect has a negative impact on the environment, and therefore we expect a positive value of it coefficient.

The capital-labor ratio serves as proxy for the composition or the structure of the economy. The expected sign of it coefficient is positive or negative. In fact, the composition effect leads to more pollution when higher capital intensity is associated with more pollution-oriented industries while the opposite effect is observed when higher capital intensity is associated to less pollution intensive activities.

Unlike the above mentioned literature, we use the energy intensity of the GDP as the proxy of the technique effect ${ }^{5}$. Energy intensity is the ratio between energy supply and gross domestic product measured at purchasing power parity. Energy intensity (EI) is an indication of energy efficiency or energy productivity and a lower ratio of EI indicates that less energy is used to produce one unit of output. Therefore, we implicitly assume that the technique effect is accompanied by reduction in the energy intensity, which in turn contributes to cub $\mathrm{CO}_{2}$ emissions.

A set of control variables is introduced in our econometric specification to avoid variable omissions bias. They include: financial development, captured by domestic credit to private sector in \% of GDP (see Shahbaz et al. [33]; Abid [23];

Table 2. Selected proxies of scale, composition and technique effects used in the literature.

\begin{tabular}{lccc}
\hline \multirow{2}{*}{$\begin{array}{c}\text { Authors } \\
\text { (year of the study) }\end{array}$} & Scale effect & Composition effect & Technique effect \\
\cline { 2 - 4 } 1) Panayotou [31] & $\begin{array}{c}\text { GDP per square } \\
\mathrm{km}\end{array}$ & $\begin{array}{c}\text { Industry share in } \\
\text { GDP }\end{array}$ & Per capita GDP \\
2) Antweiler et al. [32] & GDP per square & Capital-labor ratio & Per capita GDP \\
3) Tsurumi and & km & & \\
Managi [8] & Real GDP & Capital-labor ratio & Per capita GDP \\
4) Ling et al. [9] & Per capita GDP & Capital-labor ratio & Square of per capita \\
5) Bakehe [10] & Per capita GDP & Capital-labor ratio & GDP per square km \\
\hline
\end{tabular}

Source: authors' construction from the literature.

${ }^{5}$ Energy is indispensable output, which unfortunately accounted is cited as the main contributor to carbon emissions. Improving energy efficiency, through technological progress will help to slow down carbon emissions. 
Boutabba [34]; Shahbaz et al. [35]); population size (see Cole and Neumayer [36]; Sadorsky [37]; Liddle [38]); export and import of goods and services in share of GDP (see Jebli et al. [39]; Al-Mulali et al. [40]).

Table 3 presents an overview of the summary statistics for the variables included in our econometric model. The skewness values indicate that the distributions of all variables are right skewed. Kurtosis values show that the distributions of all variables are more concentrated than the normal distribution. The Jarque-Bera test denotes that our variables are non-normally distributed.

The correlations between the variables are presented in Table 4. It should be noted that the maximum value of the correlation coefficient is 0.59 , which is below the value of 0.7 generally used as the rule of thumb for high correlation. This suggests that neither collinearity nor multicollinearity is considered as a concern in our data.

The Variance Inflation Factor (VIF) (see Table 5) is also performed to test collinearity between our variables. The maximum VIF is 3.39 for the composition effect and is largely lower than the threshold value of 10 generally used the literature. This confirms that our model does not suffer neither from collinearity nor multicollinearity.

Table 3. Descriptive statistics.

\begin{tabular}{ccccccccc}
\hline Variable & Obs & Mean & Std. Dev. & Min & Max & Skewness & Kurtosis & Jarque-Bera \\
\hline $\mathrm{CO}_{2}$ & 437 & $26,187.54$ & $88,499.86$ & 341.031 & $503,112.4$ & 4.260 & 20.03 & $6439.62^{* * *}$ \\
Scale & 434 & $490,818.2$ & $1,663,023$ & 9338.322 & $1.13 \mathrm{e}+07$ & 1.52 & 4.44 & $202.22^{* *}$ \\
Composition & 434 & 1487.872 & 2122.723 & 508.6044 & $13,049.03$ & 2.48 & 9.48 & $1155.56^{* * *}$ \\
Technique & 437 & 8.009651 & 5.734748 & 1.91032 & 35.90422 & 1.99 & 7.31 & $612.33^{* *}$ \\
Fd & 430 & 23.38914 & 29.03755 & 0.4913875 & 160.1248 & 2.92 & 11.60 & $1923.06^{* *}$ \\
Pop & 434 & $2.28 \mathrm{e}+07$ & $3.03 \mathrm{e}+07$ & 981,764 & $1.76 \mathrm{e}+08$ & 2.83 & 12.11 & $2045.03^{* * *}$ \\
Exp & 430 & 39.67941 & 16.64399 & 11.3097 & 87.38375 & 0.82 & 2.86 & $48.26^{* *}$ \\
Imp & 430 & 33.99639 & 19.62321 & 4.428757 & 89.68583 & 0.79 & 3.04 & $44.49^{* *}$ \\
\hline
\end{tabular}

Note: ${ }^{* * *},{ }^{* *}$ and ${ }^{*}$ denotes rejection of the null hypothesis of non-normal distribution of the variables at $1 \%, 5 \%$ and $10 \%$, respectively; variables are taken before the introduction of the natural logarithm. Source: Authors' construction from the World Development Indicators (2017).

Table 4. Correlation matrix.

\begin{tabular}{|c|c|c|c|c|c|c|c|c|}
\hline & $\mathrm{CO}_{2}$ & Scale & Composition & Technique & $\mathrm{fd}$ & Pop & $\exp$ & imp \\
\hline $\mathrm{CO}_{2}$ & 1.0000 & & & & & & & \\
\hline Scale & 0.3142 & 1.0000 & & & & & & \\
\hline Composition & 0.3776 & 0.3287 & 1.0000 & & & & & \\
\hline Technique & 0.1020 & -0.1465 & -0.5713 & 1.0000 & & & & \\
\hline $\mathrm{Fd}$ & 0.4131 & 0.4846 & 0.4411 & -0.2252 & 1.0000 & & & \\
\hline Pop & 0.5217 & -0.1032 & -0.4594 & 0.5339 & -0.1902 & 1.0000 & & \\
\hline Exp & 0.1513 & 0.1460 & 0.5803 & -0.3820 & 0.1617 & -0.4303 & 1.0000 & \\
\hline $\operatorname{Imp}$ & -0.2944 & 0.0958 & 0.1950 & -0.2780 & 0.3179 & -0.5805 & 0.5947 & 1.0000 \\
\hline
\end{tabular}

Note: variables are in the log form. 
Table 5. VIF analysis.

\begin{tabular}{ccc}
\hline Variable & VIF & $1 /$ VIF \\
\hline Composition & 3.39 & 0.2946 \\
Import & 3.17 & 0.3151 \\
Export & 2.99 & 0.3343 \\
Pop & 2.29 & 0.4327 \\
FD & 2.00 & 0.4998 \\
Technique & 1.73 & 0.5789 \\
Scale & 1.35 & 0.7405 \\
\hline
\end{tabular}

Source: Authors' calculations.

\subsection{Equation and Estimation Techniques}

This study uses three panel estimation techniques to decompose the effects of economic growth on carbon emissions in SSA countries. Firstly, it uses static panel techniques (Ordinary Least Squares, random effects model, fixed effects model and Generalized Least Square). Secondly, it uses the dynamic panel specification (difference and system GMM). The first two estimation techniques serve as benchmark as they provide a mean value of the coefficients, while the quantile regression method is robust to the outlier and gives the researcher a more complete picture of the effects of the independent variables on the dependent variable (Binder and Coad [41]). The implementation procedures of these techniques advantages are described below.

\subsubsection{Static Panel Technique}

Following Panayotou [13], we adopt the following reduced-form model:

$$
\begin{aligned}
c o_{2 i t}= & \alpha_{0}+\alpha_{1} \operatorname{scal}_{i t}+\alpha_{2} \operatorname{comp}_{i t}+\alpha_{3} \text { tech }_{i t}+\alpha_{4} f d_{i t}+\alpha_{5} \text { pop }_{i t} \\
& +\alpha_{6} \exp _{i t}+\alpha_{7} i m p_{i t}+\lambda_{i}+v_{t}+\varepsilon_{i t}
\end{aligned}
$$

where $i=1, \cdots, 23$ refers to countries, $t=1996, \cdots, 2014$ is the study period. $\mathrm{CO}_{2}$ is carbon emissions in $\mathrm{kt}, s c a l$ is GDP per $\mathrm{km}^{2}$, comp is the capital labor ratio, tech is the technique effect captured by the energy intensity, $f d$ is domestic credit to the private sector as a percentage of GDP, pop is the population size (in million), exp is the export of goods and services (as a percentage of GDP) and imp is import of goods and services (as a percentage of GDP). $\alpha j(j=1, \cdots, 7)$ are the eslaciticies to be estimated, $\lambda_{i}$ is the country fixed effect, $v_{t}$ is the time fixed effect and $\varepsilon_{i t}$ is the error term. Note that all the variables are taken in natural log in order to avoid heteroskedasticity.

Equation (2) is estimated by traditional techniques, using Ordinary Least Squares (OLS), Fixed-effects model (FE) and Random effects model (RE). The selection of the appropriate model between FE and RE is done using the Hausman specification test. Several diagnostic tests are carried out in order to validate the results. Among these, we have the Wooldridge test for serial autocorrelation and the Breusch-Pagan LM test for heteroskedasticity. 


\subsubsection{Dynamic Panel Estimation Technique}

The main drawback of static estimators (OLS, RE and FE) is that the results are biased if an explanatory variable is correlated with an unobserved component of the dependent variable. Other research issues with static panel specifications include the potential endogeneity of some explanatory variables resulting from simultaneity bias, measurement errors, and the risk of omitted variables (Asiedu and Lien [42]). To overcome these issues, we adopt a dynamic specification of Equation (2) as follows:

$$
\begin{aligned}
c o_{2 i t}= & \alpha_{0}+\theta c o_{2 i t-1}+\alpha_{1} \text { scal }_{i t}+\alpha_{2} \operatorname{comp}_{i t}+\alpha_{3} \text { tech }_{i t}+\alpha_{4} f d_{i t} \\
& +\alpha_{5} \text { pop }_{i t}+\alpha_{6} \exp _{i t}+\alpha_{7} i m p_{i t}+\lambda_{i}+v_{t}+\varepsilon_{i t}
\end{aligned}
$$

where $\mathrm{CO}_{2 i t-1}$ is the lagged value of carbon emissions, all the other variables remain the same as in Equation (2). To estimate Equation (3), we refer to difference GMM of Arellano and Bond [43] and the system GMM of Arrelano and Bover [44] and Blundell and Bond [45]. Such techniques are powerful to handle endogeneity of variables and the simultaneity bias. However, the validity of the GMM estimators depends on the absence of the second order autocorrelation (AR (2)) and the validity of the instruments.

\subsubsection{Quantile Regression Approach}

Despite their advantages, estimations based on OLS, FE, RE and GMM techniques could lead to incorrect results (Cade and Noon [46]). In fact, conventional econometric approaches provide information on the mean value of the coefficients and do not describe the conditional distribution of the dependent variable. To account for such a distribution, we refer to the quantile regression technique, initially introduced by Koenker and Basset [47] and improved by Koenker and Machado [48] and Koenker and Hallock [49]. The advantage of this method lies in the fact that it considers the heterogeneity in the distribution of the dependent variable and provides a more comprehensive picture as it models the relationships at specific quantiles of the dependent variable.

Given a vector $x_{i}$ of explanatory variables, the conditional quantile of a dependent variable $y_{i}$ is expressed as follows:

$$
Q_{y_{i t}}\left(\tau / x_{i}, \alpha_{i}\right)=\alpha_{i}+x_{i t}^{\mathrm{T}} \beta_{T}
$$

From Equation (4), we formulate the following fixed effect quantile for this study:

$$
\begin{aligned}
Q_{C O_{2 i t}}\left(\tau \mid x_{i t}, \alpha_{i}\right)= & \alpha_{i}+\beta_{1 \tau} \text { scal }_{i t}+\beta_{2 \tau} \operatorname{comp}_{i t}+\beta_{3 \tau} \text { tech }_{i t}+\beta_{4 \tau} f d_{i t} \\
& +\beta_{5 \tau} \operatorname{pop}_{i t}+\beta_{6 \tau} \exp _{i t}+\beta_{7 \tau} i m p_{i t}
\end{aligned}
$$

where $\tau$ is a quantile in $(0,1), Q_{c 0_{2 i t}}\left(\tau \mid X_{i t}, \alpha_{i}\right)$ is the $\tau^{\text {th }}$ conditional quantile function, $X_{i t}$ (1, sacl, comp, tech, fd, pop, exp, imp) is a vector representing our explanatory variables.

However, our Equation (3) present two problems. Firstly, it provides inconstant estimators when the quantity of cross-sectional units closes to infinity, while the quantity of observations for each cross section-section is fixed (Kato and 
Galvao [50]). Secondly, Canay [51] suggested that it is not possible to use the standard econometric techniques to eliminate the unobserved fixed-effect.

To account for such econometric issues, we use the shrinkage method of Koenker [52]. This method consists of minimizing an asymmetrically weighted sum of absolute residuals or a penalized quantile regressor, described as follows:

$$
\left(\left(\hat{\beta}_{\tau k}\right)_{k=1, \cdots, q}\left(\alpha_{i}\right)_{i=1, \cdots, n}\right)=\underset{\substack{\left(\alpha_{i}\right)_{i=1, \cdots, n} \\\left(\beta_{\tau k}\right)_{k=1, \cdots, q}}}{\arg \min } \frac{1}{n} \sum_{i=1}^{n} \sum_{t=1}^{T} \sum_{k=1}^{K} \rho_{\tau k}\left(c o_{2_{i t}}-x_{i t}^{\mathrm{T}} \beta_{\tau k}-\alpha_{i}\right)+\lambda \sum_{i=1}^{n}\left|\alpha_{i}\right|
$$

where $\rho_{\tau_{k}}=u\left(\tau_{k}-I(\alpha \leq 0)\right)$ is the standard quantile loss function and $\lambda$ the turning parameter that shrinks the individual effects toward zero to improve the performance of the estimate of $\beta$. Following Koenker and Bassett [53], we test the parameter heterogeneity using the F-Test, which helps to determine if the slopes or the elasticities are equals across different quantiles. ${ }^{6}$ Finally, all the parameters are estimated through the Stata 12.0 software.

\section{Results and Discussions}

In this section, we report and discuss the empirical results obtained from the estimation of our equations.

\subsection{Benchmark Results: Static and Dynamic Panel Analysis}

The results of static and dynamic panel estimations are reported in Table 6. The Hausman test is used in order to select the appropriate specification between the FE and the RE models. The Hausman test yields a chi-square value of 9.49 with a p-value of 0.2194 , indicating that the REM is appropriate. However, the Breusch-Pagan LM test for heteroscedasticty and the Wooldridge test for autocorrelation indicate that the REM errors are heteroskedastic and autocorrelated. Such an issue is corrected through the GLS estimator as suggested in the literature. Regarding the GMM, the p-value associated to the Sargan and Hansen statistics exceed the conventional significance level of 0.05 , showing that our instruments are valid. In addition, the null hypothesis of the absence of second order correlation of the residuals (AR [2]) is rejected both for diff and syst GMM. $^{7}$

Our results show that the expansion of the economy or the scale effect is associated to an increase in carbon emissions. The impact is significant for all the specifications except for the system GMM where the impact is positive but non-significant. The result is in line with Turumi and Managi [8] and Ling et al. [9].

With regard to the composition effect, the results show that an increase in the capital-labor $(K L)$ ratio leads to more carbon emissions in SSA. In fact, the ${ }^{6}$ The null hypothesis of slope homogeneity $\left(\beta_{i \tau}=\beta_{i \tau}, \forall i \neq j\right)$ is tested against the alternative hypothesis of slope heterogeneity $\left(\beta_{i \tau} \neq \beta_{i \tau}, \forall i \neq j\right.$ ), where $i \tau$ and $\tau j$ refer to the $I^{\text {th }}$ and $f^{\text {th }}$ quantiles, respectively.

${ }^{7}$ Based on the diagnostic checking, our interpretations are based only on the OLS, GLS, Diff and Syst GMM. 
Table 6. Results from static and dynamic panel.

\begin{tabular}{|c|c|c|c|c|c|c|c|c|}
\hline \multirow{2}{*}{ Variables } & \multicolumn{4}{|c|}{ Static panel } & \multicolumn{2}{|c|}{ Diff GMM } & \multicolumn{2}{|c|}{ Syst GMM } \\
\hline & OLS & $\mathrm{FE}$ & $\mathrm{RE}$ & GLS & One step & Two steps & One step & Two steps \\
\hline $\mathrm{CO}_{2}\left({ }_{-1}\right)$ & & & & & $\begin{array}{l}-0.0393 \\
(0.0691)\end{array}$ & $\begin{array}{c}0.00966 \\
(0.231)\end{array}$ & $\begin{array}{l}0.434^{\star} \\
(0.254)\end{array}$ & $\begin{array}{c}0.569^{* * *} \\
(0.195)\end{array}$ \\
\hline Scale & $\begin{array}{l}0.0542^{\star *} \\
(0.0226)\end{array}$ & $\begin{array}{l}0.744^{\star * *} \\
(0.118)\end{array}$ & $\begin{array}{l}0.354^{\star * \star} \\
(0.0639)\end{array}$ & $\begin{array}{l}0.0542^{\star *} \\
(0.0224)\end{array}$ & $\begin{array}{c}1.179^{* * *} \\
(0.253)\end{array}$ & $\begin{array}{l}1.023^{* * *} \\
(0.301)\end{array}$ & $\begin{array}{c}0.0430 \\
(0.0294)\end{array}$ & $\begin{array}{l}0.00499 \\
(0.0447)\end{array}$ \\
\hline Composition & $\begin{array}{l}0.562^{* * *} \\
(0.0387)\end{array}$ & $\begin{array}{l}-0.0252 \\
(0.0370)\end{array}$ & $\begin{array}{l}0.0843^{* *} \\
(0.0355)\end{array}$ & $\begin{array}{l}0.562^{* * *} \\
(0.0384)\end{array}$ & $\begin{array}{l}0.193^{* *} \\
(0.0888)\end{array}$ & $\begin{array}{l}0.135^{* * *} \\
(0.0455)\end{array}$ & $\begin{array}{l}0.255^{* *} \\
(0.125)\end{array}$ & $\begin{array}{l}0.239^{* *} \\
(0.104)\end{array}$ \\
\hline Technic & $\begin{array}{l}0.305^{\star * *} \\
(0.0612)\end{array}$ & $\begin{array}{l}0.308^{\star * *} \\
(0.0629)\end{array}$ & $\begin{array}{l}0.197^{* * *} \\
(0.0593)\end{array}$ & $\begin{array}{l}0.305^{\star * *} \\
(0.0606)\end{array}$ & $\begin{array}{c}0.742^{\star * *} \\
(0.149)\end{array}$ & $\begin{array}{c}0.637^{\star * *} \\
(0.141)\end{array}$ & $\begin{array}{c}0.385 \\
(0.241)\end{array}$ & $\begin{array}{c}0.357 \\
(0.226)\end{array}$ \\
\hline $\mathrm{Fd}$ & $\begin{array}{l}0.609^{\star * *} \\
(0.0415)\end{array}$ & $\begin{array}{l}0.254^{* * *} \\
(0.0340)\end{array}$ & $\begin{array}{l}0.288^{\star * *} \\
(0.0351)\end{array}$ & $\begin{array}{l}0.609^{\star * *} \\
(0.0411)\end{array}$ & $\begin{array}{l}0.175^{\star} \\
(0.104)\end{array}$ & $\begin{array}{l}0.0772^{*} \\
(0.0401)\end{array}$ & $\begin{array}{c}0.328^{\star * *} \\
(0.112)\end{array}$ & $\begin{array}{l}0.312^{\star *} \\
(0.139)\end{array}$ \\
\hline Pop & $\begin{array}{l}0.864^{\star \star \star} \\
(0.0307)\end{array}$ & $\begin{array}{c}0.276 \\
(0.167)\end{array}$ & $\begin{array}{l}0.667^{\star * *} \\
(0.0727)\end{array}$ & $\begin{array}{l}0.864^{\star * *} \\
(0.0304)\end{array}$ & $\begin{array}{l}-0.358 \\
(0.466)\end{array}$ & $\begin{array}{l}0.0927 \\
(0.283)\end{array}$ & $\begin{array}{l}0.277^{\star * *} \\
(0.0818)\end{array}$ & $\begin{array}{l}0.206^{* *} \\
(0.0759)\end{array}$ \\
\hline Exp & $\begin{array}{l}0.761^{* * *} \\
(0.0755)\end{array}$ & $\begin{array}{l}0.126^{\star * *} \\
(0.0481)\end{array}$ & $\begin{array}{l}0.168^{\star * *} \\
(0.0510)\end{array}$ & $\begin{array}{l}0.761^{\star * *} \\
(0.0748)\end{array}$ & $\begin{array}{c}0.173 \\
(0.160)\end{array}$ & $\begin{array}{c}0.0741 \\
(0.0862)\end{array}$ & $\begin{array}{l}0.491^{\star *} \\
(0.194)\end{array}$ & $\begin{array}{c}0.355 \\
(0.232)\end{array}$ \\
\hline $\operatorname{Imp}$ & $\begin{array}{c}-0.809^{* * *} \\
(0.116)\end{array}$ & $\begin{array}{l}0.116^{\star *} \\
(0.0572)\end{array}$ & $\begin{array}{l}0.00721 \\
(0.0598)\end{array}$ & $\begin{array}{c}-0.809^{* * *} \\
(0.115)\end{array}$ & $\begin{array}{c}-0.631^{\star} \\
(0.358)\end{array}$ & $\begin{array}{l}-0.264^{*} \\
(0.131)\end{array}$ & $\begin{array}{c}-0.420^{\star *} \\
(0.213)\end{array}$ & $\begin{array}{c}-0.428^{\star *} \\
(0.205)\end{array}$ \\
\hline Const & $\begin{array}{c}-11.83^{* * *} \\
(0.828)\end{array}$ & $\begin{array}{l}-6.714^{* * *} \\
(1.713)\end{array}$ & $\begin{array}{l}-8.893^{* * *} \\
(1.042)\end{array}$ & $\begin{array}{c}-11.83^{* * *} \\
(0.820)\end{array}$ & & & $\begin{array}{l}-3.670^{*} \\
(1.919)\end{array}$ & $\begin{array}{l}-2.533^{*} \\
(1.281)\end{array}$ \\
\hline Obser & 423 & 423 & 423 & 423 & 377 & 377 & 402 & 402 \\
\hline Pays & 23 & 23 & 23 & 23 & 23 & 23 & 23 & 23 \\
\hline Instr & & & & & 21 & 14 & 14 & 15 \\
\hline Diagnostic check & & & & & & & & \\
\hline $\mathrm{R}^{2}$ & 0.868 & 0.750 & 0.741 & & & & & \\
\hline Hausman Prob & & & $\begin{array}{c}9.49 \\
0.2195\end{array}$ & & & & & \\
\hline $\begin{array}{l}\text { Wooldridge test } \\
\text { (Pvalue) }\end{array}$ & & & $\begin{array}{l}28.624 \\
(0.000)\end{array}$ & & & & & \\
\hline $\begin{array}{l}\text { Breusch-Pagan LM } \\
\text { test (Pvalue) }\end{array}$ & & & $\begin{array}{l}1261.59 \\
(0.000)\end{array}$ & & & & & \\
\hline AR1 & & & & & 0.348 & 0.752 & 0.0251 & 0.0195 \\
\hline AR2 & & & & & 0.171 & 0.212 & 0.214 & 0.435 \\
\hline Sargan & & & & & 0.332 & 0.140 & 0.501 & 0.252 \\
\hline Hansen & & & & & 0.308 & 0.442 & & \\
\hline
\end{tabular}

Notes: Standard errors in parentheses; Variables are in natural logarithm; ${ }^{* *}$ significance at $1 \%$; ${ }^{*}$ significance at $5 \%$; ${ }^{*}$ statistical significance at $10 \%$. Source: Authors' calculations.

estimated elasticity of carbon emissions with respect to the capital-labor ratio is between $0.135 \%$ and $0.535 \%$ and significant. This suggests that increase in the $K L$ ratio is associated with increase in the pollution-oriented activities in SSA, which lead to more carbon emissions. This result contrasts with the findings of Tsurumi and Managi [8] and Ling et al. [9], but is consistent with those of Cole and Elliott [54] whose find that the composition effect is positively related to 
carbon emissions.

The elasticity of carbon emissions with respect to energy intensity or technique effect is positive and statistically significant. This suggests that improvement in energy intensity will reduce carbon emissions in SSA. In fact, the estimated elasticity of carbon emissions with respect to the technique effect falls between 0.197 and 0.742 , suggesting that a $1 \%$ improvement in the energy intensity $^{8}$ contributes to a reduction of carbon emissions between $0.197 \%$ and $0.742 \%$. This result suggests that adoption of cleaner energies or more efficient energy sources will reduce carbon emissions in SSA countries.

For the control variables, except the share of imports in the GDP which has a negative effect on carbon emissions, the effects of the remaining variables are positive and significant. In fact, an increase in the amount of private credit to the economy (as a percentage of GDP) leads to an increase in carbon emissions. This result is robust for static and dynamic panel frameworks, and indicates that private credit to economy tend to increase the production capacity, which in turn lead to more pollution. This finding contrasts with Shahbaz et al. [33] who find that financial development reduces carbon emissions in South Africa, and consistent with Shahbaz et al. [35] and Boutabba [34] for India.

Also, an increase in the population size leads to more carbon emissions; however its effect is significant only for OLS, GLS and system GMM estimators. In fact, an increase in the population size is coupled with the increase in the consumption of conventional energies (electricity from coal, oil and natural gas), which leads to more pollution. This is in conformity with Liddle [38], Sadorsky [37], Cole and Neumayer [36] whose studies show that an increase in population size is associated to more pollution.

Finally, an increase in the ratio of exports to GDP in percentage increases carbon emissions by 0.128 to 0.761 units while the increase in the imports (as percentage of GDP) reduces carbon emissions by 0.26 to 0.809 units. This suggests that the composition of trade plays an important role in the explanation of carbon emissions. For instance, exports of primary goods (petroleum product and other raw materials) increase carbon emissions while the imports of machinery, equipment and manufactured goods reduce it. These results are consistent with Jebli et al. [39] for a panel of 24 sub-Saharan Africa countries over the period 1980-2010, but contrasts with Al-Mulali et al. [40] who find that exports have non-significant impact on carbon emissions in Vietnam while imports have a positive and significant effect on $\mathrm{CO}_{2}$.

\subsection{Alternative Estimations with Quantile Regression}

Table 7 shows the results of the quantile regression. In our study, we choose nine quantiles $\left(10^{\text {th }}, 20^{\text {th }}, 30^{\text {th }}, 40^{\text {th }}, 50^{\text {th }}, 60^{\text {th }}, 70^{\text {th }}, 80^{\text {th }}\right.$ and $\left.90^{\text {th }}\right)$ and divide these quantiles into three segments, namely, the lower quantile $\left(10^{\text {th }}, 20^{\text {th }}, 30^{\text {th }}\right.$ and

${ }^{8}$ As stated earlier, it is assumed that the technology improvement is associated to a reduction of energy intensity. 
Table 7. Quantile regression results.

\begin{tabular}{cccccccccc}
\hline Indep & \multicolumn{7}{c}{ Quantile regression } \\
\cline { 2 - 9 } Var & $10^{\text {th }}$ & $20^{\text {th }}$ & $30^{\text {th }}$ & $40^{\text {th }}$ & $50^{\text {th }}$ & $60^{\text {th }}$ & $70^{\text {th }}$ & $80^{\text {th }}$ & $90^{\text {th }}$ \\
\hline \multirow{2}{*}{ Scal } & $0.108^{* * *}$ & $0.0497^{* *}$ & 0.0354 & 0.0256 & -0.0149 & -0.00484 & -0.00988 & -0.0400 & $-0.0834^{*}$ \\
& $(0.0314)$ & $(0.0241)$ & $(0.0241)$ & $(0.0244)$ & $(0.0311)$ & $(0.0317)$ & $(0.0472)$ & $(0.0722)$ & $(0.0491)$ \\
Comp & $0.617^{* * *}$ & $0.526^{* * *}$ & $0.568^{* * *}$ & $0.538^{* * *}$ & $0.537^{* * *}$ & $0.561^{* * *}$ & $0.593^{* * *}$ & $0.636^{* * *}$ & $0.636^{* * *}$ \\
& $(0.0897)$ & $(0.124)$ & $0.0555)$ & $(0.0566)$ & $(0.0462)$ & $(0.0366)$ & $(0.0659)$ & $(0.0728)$ & $(0.0866)$ \\
Tech & $0.489^{* * *}$ & $0.392^{* *}$ & $0.294^{* *}$ & $0.248^{* *}$ & $0.239^{* * *}$ & $0.319^{* * *}$ & $0.381^{* * *}$ & $0.425^{* * *}$ & $0.330^{* *}$ \\
& $(0.0811)$ & $(0.185)$ & $(0.128)$ & $(0.107)$ & $(0.0757)$ & $(0.0987)$ & $(0.133)$ & $(0.0939)$ & $(0.134)$ \\
Fd & $0.616^{* * *}$ & $0.611^{* * *}$ & $0.551^{* * *}$ & $0.547^{* * *}$ & $0.630^{* * *}$ & $0.705^{* * *}$ & $0.737^{* * *}$ & $0.639^{* * *}$ & $0.600^{* * *}$ \\
& $(0.190)$ & $(0.0763)$ & $(0.0532)$ & $(0.0672)$ & $(0.0826)$ & $(0.0822)$ & $(0.0961)$ & $0.0702)$ & $(0.0741)$ \\
Pop & $0.819^{* * *}$ & $0.824^{* * *}$ & $0.851^{* * *}$ & $0.832^{* * *}$ & $0.823^{* * *}$ & $0.862^{* * *}$ & $0.883^{* * *}$ & $0.945^{* * *}$ & $0.996^{* * *}$ \\
& $(0.115)$ & $(0.0596)$ & $(0.0470)$ & $(0.0412)$ & $(0.0460)$ & $(0.0296)$ & $(0.0364)$ & $(0.0440)$ & $(0.0446)$ \\
Exp & $0.870^{* * *}$ & $1.074^{* * *}$ & $0.777^{* * *}$ & $0.665^{* * *}$ & $0.678^{* * *}$ & $0.670^{* * *}$ & $0.702^{* * *}$ & $0.630^{* * *}$ & $0.603^{* * *}$ \\
& $(0.158)$ & $(0.183)$ & $(0.119)$ & $(0.153)$ & $(0.0935)$ & $(0.113)$ & $(0.163)$ & $(0.156)$ & $(0.147)$ \\
Imp & $-0.971^{* * *}$ & $-1.004^{* * *}$ & $-0.778^{* * *}$ & $-0.734^{* * *}$ & $-0.850^{* * *}$ & $-0.868^{* * *}$ & $-0.902^{* * *}$ & $-0.713^{* * *}$ & $-0.635^{* * *}$ \\
& $(0.284)$ & $(0.252)$ & $(0.146)$ & $(0.197)$ & $(0.124)$ & $(0.136)$ & $(0.149)$ & $(0.180)$ & $(0.187)$ \\
Const & $-12.97^{* * *}$ & $-11.86^{* * *}$ & $-11.68^{* * *}$ & $-10.64^{* * *}$ & $-9.723^{* * *}$ & $-10.77^{* * *}$ & $-11.30^{* * *}$ & $-12.32^{* * *}$ & $-12.34^{* * *}$ \\
Obs & $(2.794)$ & $(2.249)$ & $(1.698)$ & $(1.341)$ & $(1.223)$ & $(0.635)$ & $(1.096)$ & $(1.193)$ & $(0.991)$ \\
\hline & 423 & 423 & 423 & 423 & 423 & 423 & 423 & 423 & 423 \\
\hline
\end{tabular}

Notes: Bootstrapped standard errors in parentheses; Variables are in natural log; ${ }^{* *}$ significance at $1 \%$; ${ }^{* *}$ significance at $5 \%$; ${ }^{*}$ statistical significance at $10 \%$. Source: Authors' calculations.

$\left.40^{\text {th }}\right)$, the median $\left(50^{\text {th }}\right)$ and the upper quantile $\left(60^{\text {th }}, 70^{\text {th }}, 80^{\text {th }}\right.$ and $\left.90^{\text {th }}\right)$. The standard errors are obtained through the bootstrapping approach, and the Bootstrap procedure usually performs well in the calculation of covariance matrix estimates and confidence intervals. From Table 7, we can easily observe that the impacts of the scale, composition and technique effects are heterogeneously distributed among the percentiles. This suggests that the use of quantile regression framework is appropriate in this study.

Regarding the effect of the scale of the economy, the result show that an increase in the scale of the economy has a positive effect on $\mathrm{CO}_{2}$ emissions only at the lower quantiles, the impact of the scale in the remaining percentiles being negative. However, the positive effect of the scale is significant only at the $10^{\text {th }}$ and $20^{\text {th }}$ percentiles, suggesting that an expansion in scale of the economy increases carbon emissions at lower percentiles. The elasticity of $\mathrm{CO}_{2}$ with respect to scale at the $90^{\text {th }}$ percentile is negative and significant, suggesting that the scale effect tends to reduce $\mathrm{CO}_{2}$ in countries with higher $\mathrm{CO}_{2}$ levels. This final result is contrary to the theoretical prediction on the importance of the scale effect which assumes that the scale effect is associated to more pollution. Also, the composition or structure of the production has a positive and significant effect on carbon emissions from the lower to the upper quantile. However, the elasticities of carbon emissions with respect to composition are highest in the $10^{\text {th }}$ and $90^{\text {th }}$ percentiles. Finally, improvements in energy intensity, used as proxy of technique 
effect, have a negative and significant impact on carbon emissions, and this impact is significant for all quantiles. In fact, a $1 \%$ improvement in energy intensity will reduce carbon emissions by $0.489 \%$ at the $10^{\text {th }}$ quantile, by $0.239 \%$ at the median and $0.330 \%$ at the $90^{\text {th }}$ quantile. The results on composition and technique effects are consistent with those of the static and dynamic panel.

As regards the control variables, our results reveal that an increase in the financial development indicator is associated to an increase in the level of pollution. This result is consistent across the different percentiles. Also, an increase in the size of the population also has a significant effect on carbon emissions, the highest elasticity is observed for the $90^{\text {th }}$ percentile. This suggests that increase in the population size increases $\mathrm{CO}_{2}$ emissions, the effect being stronger at the highest percentile. The share of exports in the GDP has a positive and significant impact on carbon emissions from the $10^{\text {th }}$ to the $90^{\text {th }}$ percentile. This implies that a unit increase in exports has a detrimental impact on environment. Finally, and this is consistent with static and dynamic panel results, a unit increase in the share of imports (as a percentage of GDP) tends to lower carbon emissions both at the lowest and the highest percentiles.

However, it remains important to check for the heterogeneity of the slopes associated to each quantile. In fact, we conduct the F-test of parameter heterogeneity, were the slope at the $10^{\text {th }}$ quantile is tested against the median $\left(50^{\text {th }}\right.$ quantile) and the highest quantile $\left(90^{\text {th }}\right)$, and the slope of parameter at the median is tested against the highest quantile. Results are reported in Table 8.

The F-test results do not support the null hypothesis of homogeneity of parameter for scale, composition, technique and population size. This clearly shows that it was important to account for the conditional distribution of carbon emissions in our study.

Table 8. Test for slope heterogeneity of the percentiles.

\begin{tabular}{cccc}
\hline \multirow{2}{*}{ Variables } & $(1)$ & $(2)$ & $(3)$ \\
\cline { 2 - 4 } & $10^{\text {th }}-50^{\text {th }}$ & Quantiles & \\
& & $10^{\text {th }}-90^{\text {th }}$ & $50^{\text {th }}-90^{\text {th }}$ \\
Scal & $6.63^{* *}(0.0104)$ & $6.17^{* *}(0.0134)$ & $1.31(0.2538)$ \\
Comp & $0.91(03404)$ & $0.06(0.8004)$ & $3.66^{*}(0.564)$ \\
Tech & $11.97^{* * *}(0.0006)$ & $1.29(0.2561)$ & $0.43(0.5100)$ \\
$F d$ & $0.01(0.9205)$ & $0.01(0.9079)$ & $0.17(6804)$ \\
Pop & $0.00(0.9685)$ & $3.57^{*}(0.0594)$ & $11.21(0.0009)$ \\
Exp & $0.67(0.4135)$ & $1.68(0.1953)$ & $0.50(0.4811)$ \\
Imp & $0.18(0.6718)$ & $0.89(0.3454)$ & $1.61(0.2051)$ \\
\hline
\end{tabular}

Note: $\mathrm{P}$ values are in parentheses; ${ }^{* * *}$ significance at $1 \% ;{ }^{* *}$ significance at $5 \%$; ${ }^{\star}$ statistical significance at $10 \%$. Source: Authors' calculations. 


\section{Conclusion}

This study decomposes the effects of economic growth on carbon emissions in Sub-Saharan African (SSA) countries into scale, composition and technique effects. Annual data are collected for a panel of 23 countries over the 1996-2014 period. Econometric models are estimated by static panel (REM, FEM and GLS), dynamic panel techniques (difference and system GMM) and quantile regressions approach. The second approach controls endogeneity and omission variables bias while the third helps to account for the conditional distribution of carbon emissions. The empirical results fit well and pass diagnostic tests. Two main results are derived from the study: scale and composition effects increase carbon emissions while improvement in technique of production is expected to soften carbon emissions. However, the weights of the scale, composition and technique effects are heterogeneously distributed across the $\mathrm{CO}_{2}$ emissions levels. All factors being constant, these findings indicate that the expansion in the scale of economic activities (GDP per $\mathrm{km}^{2}$ ) and the increase in the K-L ratio are expected to intensify pollution in SSA countries. However, the negative effect could be offset through the improvement in the techniques of production and the reduction of energy efficiency. Our results also indicate that financial development, population size and export (as a percentage of GDP) have positive and significant effect on carbon emissions, while an increase in imports (as a percentage of GDP) reduces in carbon emissions. The results of this study have important implications for policymakers. For instance, the results on the technique effect indicate that strategies aiming at reducing the energy intensity would slow down carbon emissions in SSA. In addition, investments in Research and Development in the energy sector will reduce energy intensity, improve energy efficiency and generate a double gain: boost economic activity at lower carbon emissions. Moving from conventional energy sources to renewable energy sources is another important solution to reduce carbon emissions embodied in the economic growth particularly in the countries at the lower quantiles of $\mathrm{CO}_{2}$, since the expansion in the scale of the economy is associated to the increase of carbon emissions. Finally, this study presents some limitations. Firstly, it uses only $\mathrm{CO}_{2}$ emissions as proxy for environmental pollution. It will be interesting to extend the research using other proxies of the environmental quality such as sulfur dioxide emissions and the deforestation caused by agriculture, and other land use. Further, our results probably provide a limited picture on the relationship between the structural effects and carbon emissions. A possible extension of this research is to investigate the causal relationship between these variables. All this could provide additional information for policymaker to formulate appropriate policies to fight against explosive $\mathrm{CO}_{2}$ emissions.

\section{Conflicts of Interest}

The authors declare no conflicts of interest regarding the publication of this paper. 


\section{References}

[1] FAO, IFAD, UNICEF, WFP and WHO (2017) The State of Food Security and Nutrition in the World 2017. Building Resilience for Peace and Food Security. Rome, FAO.

[2] World Bank (2017) World Development Indicator 2017. http://data.worldbank.org/data-catalog

[3] International Energy Agency (2017) $\mathrm{CO}_{2}$ Emissions from Fuel Combustion. http://www.iea.org/publications/freepublications/publication/CO2-emissions-fromfuel-combustion-highlights-2017.html

[4] You, W.-H., Zhu, H.-M., Yu, K. and Peng, C. (2015) Democracy, Financial Openness, and Global Carbon Dioxide Emissions: Heterogeneity across Existing Emission Levels. World Development, 66, 189-207. https://doi.org/10.1016/j.worlddev.2014.08.013

[5] Hogarth, J.R., Haywood, C. and Whitley, S. (2015) Low-Carbon Development in Sub-Saharan Africa 20 Cross-Sector Transitions. https://www.odi.org/sites/odi.org.uk/files/odi-assets/publications-opinion-files/987 8.pdf

[6] Grossman, G. and Krueger, A. (1991) Environmental Impacts of a North American Free Trade Agreement. NBER Working Paper, No. 3914, Washington. https://doi.org/10.3386/w3914

[7] World Bank (1992) World Development Report: Development and the Environment. Oxford University Press, Oxford. https://doi.org/10.1596/978-0-1952-0876-4

[8] Tsurumi, T and Managi, S. (2010) Decomposition of the Environmental Kuznets Curve: Scale, Technique, and Composition Effects. Environmental Economics and Policy Studies, 11, 19-36. https://doi.org/10.1007/s10018-009-0159-4

[9] Ling, C.H., Ahmed, K., Muhamad, R.B. and Shahbaz, M. (2015) Decomposing the Trade-Environment Nexus for Malaysia: What Do the Technique, Scale, Composition, and Comparative Advantage Effect Indicate? Environmental Science and Pollution Research, 22, 20131-20142. https://doi.org/10.1007/s11356-015-5217-9

[10] Bakehe, N.P. (2018) Decomposition of the Environmental Kuznets Curve for Deforestation in the Congo Basin. Economics Bulletin, 38, 1058-1068.

[11] Ang, J.B. (2007) $\mathrm{CO}_{2}$ Emissions, Energy Consumption, and Output in France. Energy Policy, 35, 4772-4778. https://doi.org/10.1016/j.enpol.2007.03.032

[12] Kuznets, S. (1955) Economic Growth and Income Equality. American Economic Review, 45, 1-28.

[13] Panayotou, T. (1993) Empirical Tests and Policy Analysis of Environmental Degradation at Different Stages of Economic Development. Working Paper WP238 Technology and Employment Programme. International Labor Office, Geneva.

[14] Copeland, B.R. and Taylor, M.S. (2004) Trade, Growth, and the Environment. Journal of Economic Literature, 42, 7-71. https://doi.org/10.1257/002205104773558047

[15] Brock, W.A. and Taylor, S. (2004) Economic Growth and the Environment: A Review of Theory and Empirics. NBER Working Paper No. 10854. https://doi.org/10.3386/w10854

[16] Jobert, T. and Karanfil, F. (2012) Formation et déformation de la Courbe Environnementale de Kuznets Pour les emissions de $\mathrm{CO}_{2}$. Innovations, No. 37, 11-26. https://doi.org/10.3917/inno.037.0011 
[17] Stern, D.I. (2005) Beyond the Environmental Kuznets Curve: Diffusion of Sulfur-Emissions-Abating Technology. The Journal of Environment and Development, 14, 101-124. https://doi.org/10.1177/1070496504273512

[18] Pata, U.K. (2018) Renewable Energy Consumption, Urbanization, Financial Development, Income and $\mathrm{CO}_{2}$ Emissions in Turkey: Testing EKC Hypothesis with Structural Breaks. Journal of Cleaner Production, 187, 770-779. https://doi.org/10.1016/j.jclepro.2018.03.236

[19] Hanif, I. (2018) Impact of Economic Growth, Nonrenewable and Renewable Energy Consumption, and Urbanization on Carbon Emissions in Sub-Saharan Africa. Environmental Science and Pollution Research, 25, 15057-15067. https://doi.org/10.1007/s11356-018-1753-4

[20] Ahmad, A., Zhao, Y., Shahbaz, M., Bano, S., Zhang, Z., Wang, S. and Liu, Y. (2016) Carbon Emissions, Energy Consumption and Economic Growth: An Aggregate and Disaggregate Analysis of the Indian Economy. Energy Policy, 96, 131-143, https://doi.org/10.1016/j.enpol.2016.05.032

[21] Heidari, H., Katircioglu, S.T. and Saeidpour, L. (2015) Economic Growth, $\mathrm{CO}_{2}$ Emissions, and Energy Consumption in the Five ASEAN Countries. International Journal of Electrical Power and Energy Systems, 64, 785-791. https://doi.org/10.1016/j.ijepes.2014.07.081

[22] Zoundi, Z. (2017) $\mathrm{CO}_{2}$ Emissions, Renewable Energy and the Environmental Kuznets Curve, a Panel Cointegration Approach. Renewable and Sustainable Energy Reviews, 72, 1067-1075. https://doi.org/10.1016/j.rser.2016.10.018

[23] Abid, M. (2016) Impact of Economic, Financial, and Institutional Factors on $\mathrm{CO}_{2}$ Emissions: Evidence from Sub-Saharan Africa Economies. Utilities Policy, 41, 85-94. https://doi.org/10.1016/j.jup.2016.06.009

[24] Allard, A., Takman, J., Uddin, G.S. and Ahmed, A. (2017) The N-Shaped Environmental Kuznets Curve: An Empirical Evaluation Using a Panel Quantile Regression Approach. Environmental Science and Pollution Research, 25, 5848-5861. https://doi.org/10.1007/s11356-017-0907-0

[25] Keho, Y. (2017) Revisiting the Income, Energy Consumption and Carbon Emissions Nexus: New Evidence from Quantile Regression for Different Country Groups. International Journal of Energy Economics and Policy, 7, 356-363.

[26] Alam, M., Murad, W., Noman, H.A. and, Ozturk, I. (2016) Relationships among Carbon Emissions, Economic Growth, Energy Consumption and Population Growth: Testing Environmental Kuznets Curve Hypothesis for Brazil, China, India and Indonesia. Ecological Indicators, 70, 466-479.

https://doi.org/10.1016/j.ecolind.2016.06.043

[27] Mardani, A., Streimikiene, D., Cavallaro, F., Loganathan, N. and Khoshnoudi, M. (2019) Carbon Dioxide $\left(\mathrm{CO}_{2}\right)$ Emissions and Economic Growth: A Systematic Review of Two Decades of Research from 1995 to 2017. Science of the Total Environment, 649, 31-49. https://doi.org/10.1016/j.scitotenv.2018.08.229

[28] Sarkodie, S.A. and Strezov, V. (2019) A Review on Environmental Kuznets Curve Hypothesis Using Bibliometric and Meta-Analysis. Science of the Total Environment, 649, 128-145. https://doi.org/10.1016/j.scitotenv.2018.08.276

[29] Kaika, D. and Zervas, E. (2013) The Environmental Kuznets Curve (EKC) Theory-Part A: Concept, Causes and the $\mathrm{CO}_{2}$ Emissions Case. Energy Policy, 62, 1392-1402. https://doi.org/10.1016/j.enpol.2013.07.131

[30] Dinda, S. (2004) Environmental Kuznets Curve Hypothesis: A Survey. Ecological Economics, 49, 431-455. https://doi.org/10.1016/j.ecolecon.2004.02.011 
[31] Panayotou, T. (1997) Demystifying the Environmental Kuznets Curve: Turning a Black Box into a Policy Tool. Environment and Development Economics, 2, 465-484. https://doi.org/10.1017/S1355770X97000259

[32] Antweiler, W., Copeland, B.R. and Taylor, M.S. (2001) Is Free Trade Good for The Environment? American Economic Review, 4, 877-908. https://doi.org/10.1257/aer.91.4.877

[33] Shahbaz, M., Tiwari, A.K. and Nasir, M. (2013) The Effects of Financial Development, Economic Growth, Coal Consumption and Trade Openness on $\mathrm{CO}_{2}$ Emissions in South Africa. Energy Policy, 61, 1452-1459. https://doi.org/10.1016/j.enpol.2013.07.006

[34] Boutabba, M.A. (2014) The Impact of Financial Development, Income, Energy and Trade on Carbon Emissions: Evidence from the Indian Economy. Economic Modelling, 40, 33-41. https://doi.org/10.1016/j.econmod.2014.03.005

[35] Shahbaz, M., Mallick, H., Mahalik, M.K. and Loganathan, N. (2015) Does Globalization Impede Environmental Quality in India? Ecological Indicators, 52, 379-393. https://doi.org/10.1016/j.ecolind.2014.12.025

[36] Cole, M.A. and Neumayer, E. (2004) Examining the Impact of Demographic Factors on Air Pollution. Population and Environment, 26, 5-21. https://doi.org/10.1023/B:POEN.0000039950.85422.eb

[37] Sadorsky, P. (2014) The Effect of Urbanization on $\mathrm{CO}_{2}$ Emissions in Emerging Economies. Energy Economics, 41, 147-153. https://doi.org/10.1016/j.eneco.2013.11.007

[38] Liddle, B. (2015) What Are the Carbon Emissions Elasticities for Income and Population? Bridging STIRPAT and EKC via Robust Heterogeneous Panel Estimates. Global Environmental Change, 31, 62-73. https://doi.org/10.1016/j.gloenvcha.2014.10.016

[39] Jebli, M.B., Youssef, S.B. and Ozturk, I. (2015) The Role of Renewable Energy Consumption and Trade: Environmental Kuznets Curve Analysis for Sub-Saharan Africa Countries. African Development Review, 27, 288-300. https://doi.org/10.1111/1467-8268.12147

[40] Al-Mulali, U., Saboori, B. and Ozturk, I. (2015) Investigating the Environmental Kuznets Curve Hypothesis in Vietnam. Energy Policy, 76, 123-131. https://doi.org/10.1016/j.enpol.2014.11.019

[41] Binder, M. and Coad, A. (2011) From Average Joe's Happiness to Miserable Jane and Cheerful John: Using Quantile Regressions to Analyze the Full Subjective Well-Being Distribution. Journal of Economic Behavior \& Organization, 79, 275-290. https://doi.org/10.1016/j.jebo.2011.02.005

[42] Asiedu, E. and Lien, D. (2011) Democracy, Foreign Direct Investment and Natural Resources. Journal of International Economics, 84, 99-111. https://doi.org/10.1016/j.jinteco.2010.12.001

[43] Arellano, M. and Bond, S. (1991) Some Tests of Specification for Panel Data: Monte Carlo Evidence and an Application to Employment Equations. The Review of Economic Studies, 58, 277-297. https://doi.org/10.2307/2297968

[44] Arellano, M. and Bover, O. (1995) Another Look at the Instrumental Variable Estimation of Error-Components Models. Journal of Econometrics, 68, 29-51. https://doi.org/10.1016/0304-4076(94)01642-D

[45] Blundell, R and Bond, S. (1998) Initial Conditions and Moment Restrictions in Dynamic Panel Data Models. Journal of Econometrics, 87, 115-143. https://doi.org/10.1016/S0304-4076(98)00009-8 
[46] Cade, B. and Noon, B. (2003) A Gentle Introduction to Quantile Regression for Ecologists. Frontiers in Ecology and the Environment, 1, 412-420. https://doi.org/10.1890/1540-9295(2003)001[0412:AGITQR]2.0.CO;2

[47] Koenker, R. and Bassett, G.J. (1978) Regression Quantiles. Econometrica, 46, 33-50. https://doi.org/10.2307/1913643

[48] Koenker, R. and Machado, J.A.F. (1999) Goodness of Fit and Related Inference Processes for Quantile Regression. Journal of the American Statistical Association, 94, 1296-1310. https://doi.org/10.1080/01621459.1999.10473882

[49] Koenker, R. and Hallock, K. (2001) Quantile Regression. Journal of Economic Perspectives, 15, 143-156. https://doi.org/10.1257/jep.15.4.143

[50] Kato, K. and Galvao, A.F. (2010) Smoothed Quantile Regression for Panel Data. Discussion Paper, University of Iowa, IA.

[51] Canay, I.A. (2011) A Simple Approach to Quantile Regression for Panel Data. The Econometrics Journal, 14, 368-386. https://doi.org/10.1111/j.1368-423X.2011.00349.x

[52] Koenker, R. (2004) Quantile Regression for Longitudinal Data. Journal of Multivariate Analysis, 91, 74-89. https://doi.org/10.1016/j.jmva.2004.05.006

[53] Koenker, R. and Bassett, G. (1982) Tests of Linear Hypotheses and I"1 Estimation. Econometrica, 50, 1577-1584. https://doi.org/10.2307/1913398

[54] Cole, M.A. and Elliott, R.J.R. (2003) Determining the Trade-Environment Composition Effect: The Role of Capital, Labor and Environmental Regulations. Journal of Environmental Economics and Management, 46, 363-383.

https://doi.org/10.1016/S0095-0696(03)00021-4 